\title{
Persepsi Masyarakat Kenagarian Sumani Tentang Kesiapsiagaan Bencana Gempa Bumi
}

\section{Perception of the society of Sumani Village about Disaster Preparedness}

\author{
Helfi Agustin
}

Universitas Baiturrahmah Sumatera Barat

\begin{abstract}
ABSTRAK
Kenagarian Sumani Kecamatan X Koto Singkarak, Kabupaten Solok mengalami kondisi terparah akibat gempa Sumbar pada tahun 2007. Menurut ahli geologi, Kenagarian Sumani merupakan area patahan (sesar) Sumatera, yang melintas sepanjang jalur pegunungan (Bukit Barisan) mulai dari Teluk Semangko sampai ke Banda Aceh. Tujuan penelitian untuk mengetahui persepsi masyarakat Kenagarian Sumani terhadap kesiapsiagaan bencana, karena mitos dan mispersepsi terkait kejadian bencana alam seringkali memberikan dampak yang kurang baik dalam penanggulangan bencana. Jenis penelitian adalah deskriptif. Populasi berjumlah 1376 KK, sampel 100 orang dengan kriteria pernah merasakan situasi gempa tahun 2007 dan 2009. Teknik pengambilan sampel proporsional random sampling dari 12 jorong yang ada di kenagarian. Hasil penelitian, 65\% masyarakat mempunyai paradigma konvensional terhadap bencana, $80 \%$ berpendapat masyarakat bisa melakukan usaha pengurangan risiko dampak bencana, 68\% berpendapat masih butuh bantuan medis internasional, $43 \%$ persen yakin mampu mengambil tanggung jawab atas kelangsungan hidup pasca gempa. Pendidikan tentang bencana harus terus menerus dilakukan agar masyarakat siap siaga terhadap ancaman dan memiliki kemampuan untuk mencegah, mengantisipasi, menghindar dan bangkit kembali setelah kejadian bencana.
\end{abstract}

Kata Kunci : risiko, dampak, kesiapsiagaan, bencana.

\section{ABSTRACT}

Sumani district had the worst impact by earthquake in West Sumatra in 2007. According to a geologists, Sumani is Sumateran faults area which passes along by the mountain of Bukit Barisan start from the Gulf Semangko up to Banda Aceh. The purpose of this study was to illustrate perception of the society of Sumani district about disaster preparedness, because the myths and misperceptions related to natural disasters often give unfavorable impact in disaster management. This is a descriptive research. The population are amount 1376. Sample are 100 people who has experienced in earthquake situation in 2007 and 2009. Technique sampling by using proportionale random sampling from 12 area in Sumani district. The results of the study, 65\% of peoples still have the conventional paradigm about the disaster, 80\% of peoples believe that they can participate in disaster risk reduction, 68\% of peoples thought they need international medical assistance, 43\% of peoples believe they are able to take responsibility for their own survival after the earthquake. Disaster education should be done by continually, so the peoples alert to the threat and they has ability to prevent, anticipate, dodge and re-bounce after disaster.

Key words:Risk, Impact, Alert, Disaster

\section{PENDAHULUAN}

Paradigma terhadap penanganan bencana di tingkat penduduk belum cukup banyak berubah. Masih banyak penduduk yang menganggap bahwa bencana itu merupakan suatu takdir. Hal ini merupakan gambaran bahwa paradigma konvensional masih kuat dan berakar di masyarakat. Pada umumnya masyarakat percaya bahwa bencana adalah balasan atas perbuatan dosa sehingga seseorang harus menerimanya sebagai takdir akibat perbuatannya dan mereka tidak mau lagi berusaha untuk mengambil langkah-langkah pencegahan atau penanggulangannya. (Bakornas PB, 2007).

Penanganan bencana di Indonesia cenderung kurang efektif. Titik lemah selama ini adalah penanganan bencana lebih banyak diutamakan pada fase kedaruratan, bekerja secara parsial, sektoral dan kurang terpadu, masih berpusat pada upaya pemerintah dan sebatas pemberian bantuan fisik. Namun sejak kesepakatan Yokohama, penanganan bencana mengalami perubahan paradigma yakni menitikberatkan pada partisipasi masyarakat dalam pengurangan risiko bencana dan semangat Hyogo framework for action (HFA) yang dilahirkan dari konferensi pengurangan risiko bencana di Kobe Jepang pada tahun 2005 yaitu Building the resilience of nation and communities to disasters.

Mengetahui persepsi masyarakat terkait kejadian bencana alam merupakan suatu hal yang penting dalam penanggulangan bencana, karena mitos dan mispersepsi terkait kejadian bencana alam seringkali memberikan penanggulangan bencana.

\footnotetext{
${ }^{1}$ Alamat Korespodensi : Helfi Agustin, Hp: 085274554097, Email : helfiagustin@gmail.com
} 
Kenagarian Sumani merupakan salah satu kenagarian yang ada di Kecamatan Koto X Koto Singkarak, Kabupaten Solok, Propinsi Sumbar. Pada saat gempa tahun 2007, Kenagarian Sumani termasuk daerah yang mengalami kondisi yang cukup parah akibat gempa. Menurut ahli geologi, Kenagarian Sumani merupakan area patahan (sesar) Sumatera, yang melintas sepanjang jalur pegunungan (Bukit Barisan) mulai dari Teluk Semangko sampai ke Banda Aceh. Sehingga untuk program penanggulangan bencana berbasis masyarakat di Kenagarian Sumani, penting diketahui persepsi masyarakat tentang bencana. Bencana dalam penelitian ini hanya dibatasi pada gempa bumi, karena kenagarian Sumani pernah mengalami gempa bumi yang berdampak besar terhadap kondisi masyarakatnya.

Pengalaman bencana dan kondisi geologi tersebut merupakan suatu pelajaran yang seharusnya mengubah pandangan masyarakat Kenagarian Sumani tentang kewaspadaan terhadap bencana. Jika cerita tentang bencana diwariskan pada generasi berikutnya, maka akan selalu diingat dan diperoleh suatu hikmah yang menjadi pelajaran kesiapsiagaan terhadap bencana. Penelitian ini bertujuan untuk menggambarkan persepsi masyarakat tentang kesiapsiagaan terhadap bencana gempa bumi.

\section{METODE}

Jenis penelitian adalah penelitian deskriptif. Survey dilakukan terhadap masyarakat di 12 jorong di kenagarian Sumani Kecamatan X Koto Singkarak Kabupaten Solok. Data dikumpulkan dengan penyebaran angket yang dilakukan di bulan Maret April 2013. Unit sampel adalah salah satu anggota keluarga yang hanya diwakili oleh satu sampel dari satu KK. Jumlah KK terdiri atas 1376 KK. Pengambilan sampel ini menggunakan rumus :

$$
\begin{aligned}
\mathrm{n} & =\frac{\left(\mathrm{z}_{1}-\alpha / 2\right)^{2} \cdot \mathrm{p}(1-\mathrm{p}) \mathrm{N}}{\mathrm{d}^{2}(\mathrm{~N}-1)+\left(\mathrm{z}_{1}-\alpha / 2\right)^{2} \cdot \mathrm{p}(1-\mathrm{p})} \\
& =\frac{(1,96)^{2} \times 0,5 \times 0,5 \times 1376}{(0,1)^{2}(1375)+(1,96)^{2} \times 0,5 \times 0,5} \\
& =100 \text { orang }
\end{aligned}
$$

Keterangan :

$\mathrm{N}=$ Besar Populasi $=1376$

$\mathrm{p}=0.5$

$\mathrm{d}=$ Penyimpangan atau ketetapan yang diinginkan sebesar $(0,1)$

Sampel diambil secara proporsional dari 12 Jorong yang ada di Kenagarian Sumani. Selanjutnya sampel dipilih secara simple random sampling. Kriteria pengambilan sampel adalah masyarakat yang saat penelitian bertempat tinggal di Kenagarian Sumani dan merasakan situasi gempa Sumbar tahun 2007 atau gempa 2009.

Data yang sudah terkumpul, dianalisis secara univariat untuk mendeskripsikan setiap item pertanyaan mengenai persepsi terhadap kesiapsiagaan.

\section{HASIL}

\section{Karakteristik Responden}

Responden dengan jenis kelamin perempuan lebih banyak (69\%) daripada laki-laki. Usia responden yang paling banyak terjaring adalah usia 26-50 tahun $(68 \%)$, usia $<25$ tahun $11 \%$, selebihnya usia $>51$. Usia termuda adalah 19 tahun dan tertua 80 tahun.

\section{Persepsi tentang Kesiapsiagaan Bencana}

Persepsi masyarakat tentang kesiapsiagaan bencana dinilai berdasarkan kesetujuan masyarakat terhadap pernyataan positif yang peneliti nyatakan di dalam angket. Dari tabel dapat dilihat bahwa hampir seluruh pernyataan dijawab setuju oleh lebih dari separuh masyarakat. Yang menarik adalah pada umumnya $(>80 \%)$ masyarakat setuju dapat berpartisipasi dalam kesiapsiagaan bencana. Namun sebaliknya kurang dari separuh $(=<43 \%)$ responden menyatakan masyarakat ragu terhadap kemampuan mereka dalam mengambil alih tanggung jawab atas kelangsungan hidup dan tidak yakin akan lama masa pemulihan setelah bencana. Perilaku masyarakat yang berhubungan dengan bencana sangat dipengaruhi oleh pandangan/persepsi mereka terhadap bencana itu sendiri. Tabel berikut adalah tabel tentang persepsi masyarakat yang variabel pernyataannya diadopsi dari mitos-mitos yang dimuat dalam buku Pan America Health Organization, tahun 2006.

Tabel 1

Persepsi Masyarakat Kenagarian Sumani tentang Kesiapsiagaan Bencana

\begin{tabular}{|l|l|c|c|}
\hline No. & \multicolumn{1}{|c|}{ Persepsi } & $\begin{array}{c}\text { Setuju } \\
(\%)\end{array}$ & $\begin{array}{c}\text { Tidak } \\
\text { Setuju (\%) }\end{array}$ \\
\hline 1. & Pasrah terhadap kejadian bencana & 65 & 35 \\
\hline 2. & Masyarakat dapat berkontribusi dalam penanggulangan bencana & 89 & 49 \\
\hline 3. & Kewaspadaan masyarakat dapat mengurangi risiko dampak bencana & 81 & 19 \\
\hline 4. & Penduduk rentan adalah wanita, lansia, anak dan orang miskin & 63 & 37 \\
\hline 5. & Urgensi terhadap bantuan internasional & 68 & 32 \\
\hline 6. & Penduduk mampu mengambil tanggung jawab atas kelangsungan hidup mereka sendiri & 43 & 57 \\
\hline 7. & Pencegahan epidemi dan wabah penyakit & 77 & 23 \\
\hline 8. & Tinggal di penampungan sementara & 78 & 22 \\
\hline 9. & Masa pemulihan bencana tidak memakan waktu terlalu lama & 40 & 60 \\
\hline
\end{tabular}




\section{PEMBAHASAN}

\section{Persepsi terhadap bencana}

Hasil penelitian menemukan lebih dari separuh (65\%) responden menjawab pasrah seandainya sewaktu-waktu terjadi bencana gempa bumi. Alasan masyarakat adalah karena bencana tidak dapat diperkirakan kapan waktunya dan siapa yang akan menjadi korban bencana. Hal ini sesuai dengan pernyataan peneliti UGM Dwikorita Karnawati pada sebuah berita di VivaNews bahwa di Indonesia masih banyak penduduk yang menganggap bencana itu merupakan suatu takdir. Hal ini merupakan gambaran bahwa paradigma konvensional masih kuat dan berakar dalam masyarakat.

Berbeda dengan penelitian Fatmah di Jakarta (2009) tentang model mitigasi bencana kebakaran berbasis masyarakat. Temuan Fatmah, informan sudah mempunyai kesadaran untuk melakukan pencegahan, hanya saja perlu kesamaan persepsi diantara masyarakat bahwa kerugian jika terjadi kebakaran, tidak hanya dialami oleh individu akan tetapi masyarakat secara keseluruhan. Kebersamaan masyarakat sangat diperlukan untuk mencegah kebakaran.

Temuan penelitian ini menjadi berbeda mungkin disebabkan oleh adanya perbedaan karakteristik bencana, Fatmah meneliti mitigasi bencana kebakaran yang secara karakteristik lebih mudah dikenali penyebab serta cara pencegahannya. Sedangkan bencana gempa bumi lebih unpredictable". Selain itu karakteristik masyarakat juga sangat berbeda, penelitian Fatmah masyarakat perkotaan (Jakarta), sedangkan di Kenagarian Sumani adalah masyarakat pedesaan yang masih menganut nilai dan kepercayaan bahwa bencana adalah bagian dari takdir/kehendak yang Maha Kuasa.

Menurut Bakornas Penanggulangan Bencana (2007), paradigma terhadap penanganan bencana di tingkat penduduk belum cukup banyak berubah. Pada umumnya

masyarakat percaya bahwa bencana adalah balasan atas perbuatan dosa sehingga seseorang harus menerimanya sebagai takdir akibat perbuatannya dan mereka tidak mau lagi berusaha untuk mengambil langkah - langkah pencegahan atau penanggulangannya.

Bencana alam dapat terjadi secara tiba-tiba maupun melalui proses yang berlangsung perlahanlahan sehingga masih dapat diramalkan. Akan tetapi khusus bencana gempa bumi, sampai saat ini hampir tak bisa diperkirakan secara akurat kapan dan dimana akan terjadinya serta berapa kekuatannya. Namun demikian dampak bencana gempa bumi masih bisa diminimalisir dengan meningkatkan kemampuan untuk merespon bencana (misalnya dengan keterampilan dalam penyelematan diri saat gempa terjadi) dan mengurangi kerentanan terhadap dampak bencana (misalnya membangun rumah yang tahan terhadap gempa hingga kekuatan tertentu). Bencana terjadi karena faktor ancaman bertemu dengan faktor kerentanan dan ketidakmampuan/ kemampuan yang rendah untuk menanggapi ancaman itu, Gabungan keduanya menyebabkan terganggunya kehidupan masyarakat seperti kehancuran rumah, kerusakan harta benda serta korban jiwa. Umumnya bahaya bencana dapat terjadi di mana saja dengan sedikit atau tanpa peringatan, maka sangat penting bersiapsiaga terhadap bahaya bencana untuk mengurangi risiko dampaknya. (Yayasan Jambo Minda : 2010).

\section{Persepsi tentang tanggung jawab dalam penanggulangan bencana}

Hasil penelitian menemukan pada umumnya (89\%) responden setuju dengan pernyataan bahwa masyarakat mempunyai kontribusi dalam penanggulangan bencana, sementara separuh $(51 \%)$ responden setuju dengan pernyataan bahwa perlindungan masyarakat dari ancaman bencana dan penanggulangannya merupakan tanggung jawab dan urusan pemerintah.

Hanya separuh responden yang menjawab setuju dengan peran pemerintah, namun sebagian besar masyarakat yakin terhadap kontribusi mereka dalam penanggulangan bencana, seolah-olah menunjukkan keraguan masyarakat dan terus mempertanyakan dimana sebenarnya peran pemerintah dalam penanggulangan bencana dan sejauhmana pemerintah telah memberi perlindungan terhadap masyarakat? Peran pemerintah dapat dikatakan minim dan lambat pada sejumlah kasus bencana. Bantuan kepada masyarakat juga tersendat-sendat karena tidak terjalinnya koordinasi antar departemen sehingga bencana terkesan ditangani secara parsial. (Majalah Interaksi No.2, 2007)

UU nomor 24 tahun 2007 telah mengatur hak dan kewajiban masyarakat, serta tanggung jawab dan wewenang pemerintah dalam penanggulangan bencana. Diantaranya Tanggung jawab pemerintah dalam penanggulangan bencana adalah: pengurangan risiko bencana dengan program pembangunan, perlindungan masyarakat dari dampak bencana, pemenuhan hak masyarakat dan pengungsi secara adil, pemulihan kondisi dari dampak bencana, pengalokasian anggaran penanggulang-an bencana, pemeliharaan arsip/ dokumen otentik dan kredibel dari ancaman dan dampak bencana. Sedangkan wewenang pemerintah dalam penanggulangan bencana adalah: penetapan kebijakan penanggulangan bencana selaras dengan kebijakan pembangunan nasional, pembuatan perencanaan pembangunan, penetapan status dan tingkatan bencana nasional dan daerah, penentuan kebijakan kerja sama dengan pihak lain, perumusan kebijakan, pengendalian pengumpulan dan penyaluran uang atau barang.(Wacana, 2012). 
Paradigma penanganan bencana telah mengalami pergeseran. Dua puluh tahun lalu pengelolaan bencana lebih kepada pengelolaan bantuan kemanusiaan yang diselenggarakan oleh beberapa tenaga professional yang menangani korban. Saat ini penanggulangan bencana lebih menekankan paradigma pengurangan risiko bencana. (Bakornas PB, 2007).

Paradigma pengurangan risiko bencana merupakan perpaduan dari sudut pandang teknis dan ilmiah dengan perhatian kepada faktor sosial, ekonomi dan politik sehingga lebih melibatkan beragam disiplin. Dalam perencanaan paradigma pengurangan bencana, bertujuan untuk meningkatkan kemampuan masyarakat untuk mengelola dan menekan risiko terjadinya bencana. Secara teori ada tiga hal penting terkait dengan perubahan paradigma yaitu 1) penanggulangan bencana tidak lagi berfokus pada aspek tanggap darurat tetapi lebih pada keseluruhan manajemen risiko. 2) perlindungan masyarakat dari ancaman bencana oleh pemerintah merupakan hak azasi rakyat 3) penanggulangan bencana bukan sematamata kewajiban pemerintah. (Bakornas PB, 2007)

$\mathrm{Di}$ sisi lain masyarakat juga memiliki kewajiban yang harus ditunaikan kepada Negara dan sebaliknya mendapat penghormatan, perlindungan dan pemenuhan hak warga oleh Negara dalam penanggulangan bencana yakni: mendapatkan perlindungan social dan rasa aman, mendapatkan pendidikan, pelatihan, dan keterampilan, mendapatkan informasi secara tertulis dan atau lisan, berperan serta dalam perencanaan, pengoperasian, dan pemeliharaan program penyediaan bantuan, berpartisipasi dalam pengambilan keputusan, melakukan pengawasan sesuai dengan mekanisme, setiap orang yang terkena bencana berhak mendapatkan bantuan pemenuhan kebutuhan dasar, setiap orang berhak memperoleh ganti kerugian disebabkan oleh kegagalan konstruksi. Kewajiban masyarakat dalam penanggulangan bencana adalah menjaga kehidupan sosial masyarakat yang harmonis, memelihara keseimbangan, keserasian, keselarasan dan kelestarian fungsi lingkungan hidup, melakukan kegiatan penanggulangan bencana, memberikan informasi yang benar kepada publik tentang penanggulangan bencana.

Masyarakat memberi kontribusi besar pada penanggulangan bencana. Perilaku individu-individu dalam sebuah masyarakat sehubungan dengan bencana sangat dipengaruhi oleh pandangan mereka terhadap bencana itu sendiri (persepsi terhadap bencana). Mitos atau mispersepsi terkait kejadian bencana alam seringkali memberikan dampak yang kurang baik dalam penanggulangan bencana.

Pada tahap mengantisipasi bencana, langkahlangkah yang dilakukan dikategorikan ke dalam mitigasi, pencegahan dan tanggap darurat menghadapi bencana. Mitigasi adalah tindakan mengurangi konsekuensi bencana dan marabahaya. Mitigasi merupakan upaya pengurangan kerawanan dan kerapuhan yang ditemukan dalam komunitas, baik sebelum maupun sesudah bencana. Mitigasi yang dilakukan sebelum bencana misalnya sebelum terjadi gempa bumi struktur bangunan dibuat menjadi tahan gempa. Mitigasi yang dilakukan setelah bencana terjadi, merupakan bagian integral dari rekonstruksi atau rehabilitasi. (Yayasan IDEP, 2007)

Kemampuan tanggap darurat terhadap bencana dan sumber daya yang cukup merupakan modal dasar masyarakat untuk menyelamatkan diri dari bencana. Tahapan dalam merencanakan tanggap darurat terhadap bencana membentuk suatu siklus spiral. Pada tahap peringatan, macam-macam peringatan dapat disiarkan sehingga penduduk dapat bersiap-siap menghadapi ancaman marabahaya serta dapat meminimalkan dampak buruknya.

Kesepakatan internasional juga telah banyak mendorong pemerintah Indonesia untuk merubah pandangannya dalam penanganan bencana, dimana mengundang keterlibatan masyarakat menjadi bagian dari strategi pemerintah dalam penanggulangan bencana, sehingga penanggulangan bencana bukan hanya urusan pemerintah tetapi juga menjadi urusan bersama seluruh elemen masyarakat dimana pemerintah sebagai penanggungjawabnya.

Uluran tangan dari masyarakat dunia usaha lembaga resmi non pemerintah/swasta dan LSM juga menjadi sangat berharga dalam membantu penanganan korban bencana alam dan penanggulangan bencana secara keseluruhan. (Interaksi No.2, 2007).

\section{Persepsi tentang kesiapsiagaan dan pengurangan risiko dampak bencana}

Dari hasil penelitian diperoleh umumnya (81\%) responden menyatakan setuju bahwa kerugian akibat dampak bencana gempa bumi dapat dikurangi dengan kewaspadaan dan kesiapsiagaan dalam menghadapi bencana gempa bumi. Dari penelitian ini nampaknya pendidikan terhadap masyarakat dalam membangun kembali rumahnya yang menggunakan tokoh masyarakat nasional asal Minang yaitu Jajang C. Noor cukup melekat dalam ingatan masyarakat. Jajang C. Noor dengan kalimat singkatnya "bukan gempanya, namun bangunannya" yang ditayangkan di TV local, billboard yang dipasang di jalan raya SumaniBukittinggi, spanduk yang dibagikan oleh pemerintah ke toko-toko bahan bangunan telah cukup mempengaruhi pikiran masyarakat.

Gempa adalah getaran atau goncangan yang terjadi ketika dari lempengan dari kerak bumi bergerak satu sama lain. Pergesekan antara dua lempeng tersebut akan menimbulkan goncangan di permukaan. Gempa bumi dapat menyebabkan kerusakan yang hebat dan luas pada sarana seperti bangunan dan jalan-jalan. Gempa juga dapat diikuti bencana alam berbahaya seperti tanah longsor. Dampak bencana gempa bumi 
adalah kerugian harta bencana hingga jatuhnya korban jiwa. Biasanya korban jiwa terjadi karena tertimpa bagian-bagian bangunan roboh atau obyek berat lain seperti pohon dan tiang listrik. Orang sering terperangkap dalam bangunan runtuh. Gempa bumi sering diikuti oleh gempa susulan dalam beberapa jam atau hari atau bahkan minggu setelah yang pertama, walaupun sering tidak sekuat yang pertama. Ancaman gempa susulan adalah runtuhnya bangunan yang telah goyah akibat gempa pertama (Yayasan Jambo Minda : 2010).

Memang hampir tidak mungkin untuk mencegah terjadinya suatu bencana yang sifatnya alami, tetapi dampak kerusakan yang ditimbulkannya dapat diminimalkan. Pada sebagian besar kasus, aktivitas mitigasi ditujukan untuk mengurangi kerentanan sistim atau mengurangi besarnya bahaya. Paradigma ini disebut dengan paradigma pengurangan risiko bencana yaitu suatu cara pandang dalam penanggulangan bencana dimana setiap individu dalam masyarakat di suatu daerah diperkenalkan dengan berbagai ancaman yang ada di wilayahnya, bagaimana cara mengurangi ancaman (hazard), dan kerentanan (vulnerability) yang dimiliki, seta meningkatkan kemampuan (capacity) masyarakat dalam menghadapi setiap ancaman. Hubungan antara ancaman, kerentanan, risiko dan kejadian bencana digambarkan secara matematis :

\section{Risiko bencana $=\underline{\text { Bahaya } \mathrm{x} \text { kerentanan }}$ \\ Kemampuan}

Dalam kaitan ini, bahaya menunjukkan kemungkinan terjadinya kejadian bencana alam maupun buatan manusia. Kerentanan menunjukkan kerawanan yang dihadapi suatu masyarakat dalam menghadapi ancaman tersebut. Ketidakmampuan merupakan kelangkaan upaya atau kegiatan yang dapat mengurangi korban jiwa atau kerusakan. Dengan demikian semakin tinggi bahaya, kerentanan dan ketidakmampuan, maka semakin besar pula risiko bencana yang dihadapi.

Sedangkan tujuan khusus dari upaya kesiapsiagaan bencana adalah menjamin bahwa sistim, prosedur, dan sumber daya yang tepat siap di tempatnya masing-masing untuk memberikan bantuan yang efektif dan segera bagi korban bencana sehingga dapat mempermudah langkah-langkah pemulihan dan rehabilitasi layanan.

\section{Persepsi tentang kerentanan penduduk}

Dari hasil penelitian didapati lebih dari separuh (63\%) responden menyatakan bencana gempa bumi dapat menimbulkan korban jiwa tanpa pandang bulu, dengan kata lain setiap orang rentan terhadap bencana, sehingga bencana dapat menghilangkan nyawa setiap orang secara acak. Sebagian besar responden (78\%) juga setuju bahwa kelompok yang paling rentan terhadap serangan gempa adalah wanita, anak-anak, lansia, orang cacat (disable) dan penduduk miskin.

Nagari Sumani yang memiliki 12 jorong, dengan jumlah penduduk yang berbeda-beda pada setiap jorong. Dari data kependudukan Kenagarian Sumani menunjukkan jumlah penduduk wanita lebih banyak daripada laki-laki, jumlah penduduk laki-laki sebanyak 2.737 jiwa dan penduduk perempuannya 2.903 jiwa. Adapun jumlah penduduk yang terbanyak pada tahun 2012 terdapat pada Jorong Kapuh dan jumlah penduduk terkecil terdapat pada Jorong Kajang.

Berdasarkan usia, penduduk Nagari Sumani terbanyak terdapat pada usia 22-64 tahun yaitu dengan jumlah penduduk laki-laki pada usia tersebut adalah 1.547 jiwa dan penduduk perempuannya adalah 1.701 jiwa. Jumlah penduduk usia 5-6 tahun yaitu laki-laki sebanyak 151 jiwa, dan perempuan sebanyak 169 jiwa.

Jumlah penduduk berdasarkan tingkat pendidikan, terbanyak adalah dengan tingkat pendidikan SD/sederajat yaitu 2705 jiwa hanya sedikit penduduk dengan tingkat pendidikan S1/sederajat. Nagari Sumani masih rendah dalam sumber daya manusia yang ada. Penduduk yang berusia lanjut dan kanak-kanak merupakan kelompok masyarakat yang akan mengalami situasi yang paling berat saat serangan gempa terjadi.(Profil Kenagarian Sumani, 2013)

Kerentanan merupakan suatu kondisi dari suatu komunitas atau masyarakat yang mengarah atau menyebabkan ketidakmampuan dalam menghadapi bencana. Tingkat kerentanan adalah suatu hal yang penting untuk diketahui sebagai salah satu faktor yang berpengaruh terhadap terjadinya bencana, karena bencana baru akan terjadi bila "bahaya" terjadi dan masyarakat berada pada kondisi yang rentan. Tingkat kerentanan dapat ditinjau dari kerentanan fisik, (infrastruktur), sosial kependudukan, dan ekonomi. Kerentanan sosial menggambarkan kondisi tingkat kerapuhan sosial dalam menghadapi bahaya (hazard). Pada kondisi sosial yang rentan, maka jika terjadi bencana dapat dipastikan akan menimbulkan dampak kerugian yang besar. Beberapa indikator kerentanan sosial antara lain persentase penduduk usia balitalansia dan penduduk wanita serta kepadatan penduduk.

Kerentanan juga terjadi karena ketidakpahaman terhadap ancaman. Menurut Bakornas penanggulangan bencana, salah satu penyebab timbulnya bencana di Indonesia adalah kurangnya pemahaman terhadap karakteristik ancaman bencana. Seringkali seolah-olah bencana terjadi secara tiba-tiba sehingga masyarakat kurang siap menghadapinya, akibatnya banyak timbul kerugian bahkan korban jiwa. Padahal sebagain besar bencana dapat diprediksi kejadiannya dengan tingkat ketepatan peramalan sangat tergantung dari ketersediaan dan kesiapan alat serta sumber daya manusia. (Bakornas PB, 2007) 
Risiko tambahan kerawanan adalah kerawanan potensial yang baru akan bermanifestasi setelah terjadinya bencana misalnya penjarahan, berkembangnya penyakit-penyakit infeksi. Walaupun baru bermanifestasi setelah bencana terjadi, pada fase pra bencana kondisi ini seharusnya sudah dapat diantisipasi dan diidentifikasi sebagai kerawanan potensial yang tersembunyi. Salah satu cara mengantisipasinya adalah melalui pendidikan formal tentang moral pembentuk karakter bangsa. Misalnya ketika terjadi tsunami di Fukushima Jepang pada 11 Maret 2011, tidak ada laporan mengenai penjarahan karena masyarakat Jepang sudah terbiasa dengan tata sosial yang tidak memberi peluang bagi penjarahan. (Purwana, 2013).

\section{Persepsi tentang urgensi terhadap bantuan internasional}

Sebagian besar responden (68\%) menyatakan bahwa mereka segera membutuhkan berbagai jenis bantuan internasional setelah bencana, hanya $43 \%$ responden yang setuju dengan pernyataan bahwa sebagian besar kebutuhan dapat dipenuhi oleh korban, pemerintah dan lembaga lokal. Bahkan hanya 32\% responden setuju dengan pernyataan bahwa masyarakat sebenarnya dapat mencukupi sendiri kebutuhan dasar untuk hidupnya sebelum, saat dan setelah bencana. Menurut $69 \%$ responden, sebaiknya pemerintah segera menerima relawan asing yang mempunyai latar belakang kedokteran setelah serangan gempa terjadi karena keahlian medis akan sangat dibutuhkan di wilayah yang terkena gempa.

Reaksi terburu-buru yang yang tidak didasarkan pada hasil evaluasi hanya akan menimbulkan kekacauan. Karena berbagai alasan, masyarakat setempat kadang tidak mengetahui apa sebenarnya yang mereka perlukan, sehingga memperoleh bantuan dengan cara yang tidak diharapkan atau tidak sesuai dengan kebutuhan mereka. Lebih baik jika menunggu sampai kebutuhan yang sebenarnya sudah didapat dari hasil evaluasi. (Yayasan IDEP, 2010).

Semua Negara harus berusaha mewujudkan upaya penanggulangan bencana secara mandiri. Namun ada saat-saat dimana bantuan internasional memang dibutuhkan. Kebijakan untuk bantuan pemulihan internasional berdasarkan hasil konsultasi dengan intitusi pemerintah yang memiliki otoritas berdasarkan kajian cepat terhadap kebutuhan atau tipe spesisifik bantuan. Waktu yang dibutuhkan untuk mendapat hasil kajian setidaknya juga menjadi salah satu alasan penting mengapa masyarakat perlu mempersiapkan diri untuk menghadapi bencana.

Program pemulihan juga perlu dipersiapkan kegiatannya sehingga pemulihan masyarakat tidak bergantung terlalu lama terhadap bantuan asing, karena kenyataannya ketertarikan dunia internasional dalam memberikan bantuan akan berkurang sejalan dengan semakin besarnya kebutuhan dan kelangkaan sumber daya. Masyarakat perlu dipersiapkan dan mutlak membutuhkan pendidikan tentang bencana. Faktanya sebagian besar kebutuhan dapat dipenuhi oleh korban, pemerintah/lembaga lokal mereka, bukan oleh campur tangan orang asing. (Pan America Health Organization, 2006).

\section{Persepsi tentang kemampuan penduduk untuk mengambil tanggung jawab atas kelangsungan hidup mereka sendiri}

Berdasarkan temuan penelitian terlihat ketidakyakinan masyarakat terhadap kemampuan diri untuk menyelesaikan masalah mereka pasca gempa bumi dari sedikitnya (hanya $43 \%$ ) persentase jawaban responden yang menyatakan bahwa kebutuhan dapat dipenuhi oleh korban, pemerintah dan lembaga lokal tanpa campur tangan orang asing/lembaga internasional. Terdapat $68 \%$ responden yang berpendapat bahwa korban bencana terlalu syok dan tidak berdaya untuk mengambil tanggung jawab atas kelangsungan hidup mereka. Namun ketika dihadapkan pada pernyataan bahwa masyarakat menemukan kekuatan baru selama masa darurat, contohnya sikap spontan relawan, kebanyakan orang menanggapi bencana secara cepat dan dermawan, dan $75 \%$ responden setuju dengan pernyataan tersebut. Pada dasarnya sikap kegotongroyongan yang dimiliki oleh bangsa Indonesia adalah kekuatan besar masyarakat yang tidak sedang ditimpa bencana untuk mengulurkan bantuan kepada penduduk yang wilayahnya saat itu ditimpa bencana.

Dalam penanggulangan bencana, masyarakat disiapkan agar mampu melakukan upaya untuk mencegah/menghindari, memulihkan diri dan mengurangi dampak bencana sehingga masyarakat menjadi lebih aman, mandiri dan tahan terhadap bencana. Penanggulangan bencana berbasis masyarakat penting dilakukan dengan pertimbangan bahwa saat keadaan darurat, warga setempatlah yang harus bertindak untuk menolong keluarga mereka, tetangga dan sesama dengan menggunakan sumber daya yang ada.

Pengetahuan masyarakat mengenai lingkungan dan budaya setempat merupakan hal penting untuk mengurangi kerentanan di masyarakat. Penanggulangan bencana berbasis masyarakat dapat memberdayakan anggota masyarakat untuk bekerjasama dalam membuat rencana yang tepat guna. Masyarakatlah yang akan menghadapi bencana langsung, bukan pemerintah atau lembaga lainnya. Karena itulah mengapa masyarakat dapat berperan penting dan harus terlibat dalam pemulihannya sendiri. Masyarakat bisa berperan aktif dalam membangun kembali lingkungannya sendiri karena mereka lah yang paling memahami kebutuhannya dan apa yang terbaik untuk mereka. Setiap orang mempunyai hak untuk hidup sejahtera dan aman dari bencana. Masyarakat 
yang menghadapi risiko bencana akan memperoleh manfaat dengan memahami apa yang harus dilakukan saat bencana terjadi. (Yayasan IDEP, 2010).

Manfaat penanggulangan bencana berbasis masyarakat: diantaranya adalah mendidik masyarakat dan mengembangkan pengetahuan yang sudah ada sehingga meningkatkan kewaspadaan terhadap bencana dan risiko yang akan dihadapi, meransang masyarakat agar lebih siap untuk menghadapi bencana di daerah mereka dan membantu memahami bagaimana dan dimana bencana mungkin bisa terjadi, memperkuat kemampuan masyarakat dalam menanggulangi bencana, seperti membuat rencana jalur pengungsian dan menjalin hubungan dengan lembaga/instansi yang bisa membantu dalam penanggulangan bencana, mengembangkan atau membentuk kelompok masyarakat penanggulangan bencana yang dapat membangun dan menjaga kemampuan masyarakat dalam penanggulangan bencana, serta meningkatkan kesadaran masyarakat mengenai lingkungan alam dan perannya dalam mengurangi risiko bencana. (Yayasan IDEP, 2010).

\section{Persepsi tentang pencegahan epidemi dan wabah penyakit.}

Berdasarkan hasil penelitian lebih dari separuh (77\%) responden menyatakan setuju bahwa epidemi dan wabah penyakit tidak dapat dihindari setelah berlangsungnya suatu bencana. Mitos di atas sepertinya juga dipercayai oleh responden di Kenagarian Sumani, padahal epidemi tidak terjadi begitu saja setelah bencana. Pencegahan penyakit dapat dilakukan dengan perbaikan sanitasi dan pendidikan kesehatan kepada masyarakat. Kunci pencegahan penyakit terletak pada kebersihan pribadi (hygiene personal) dan perbaikan kondisi sanitasi.(Pan America Health Organization, 2006).

Sistim penyediaan air minum dan pembuangan air kotor di daerah kota dan pedesaan merupakan sistim yang paling rentan terhadap bencana alam. Jika persediaan air menjadi tercemar akibat bencana, risiko penduduk tertular penyakit semakin tinggi, dan sanitasi pun dengan cepat akan memburuk. Dampak kesehatan yang tidak langsung ini seringkali sulit untuk dievaluasi dan biaya untuk memperbaiki sistim ini umumnya sangat tinggi. (Kessaram, 2011).

Efek kesehatan jangka panjang akibat bencana yang menimbulkan sejumlah korban yang diharus lebih lama di rumah sakit, contohnya pasien paraplegik yang mengalami kerusakan otak parah, amputasi dan sepsis kronis, serta efek kesehatan tidak langsung akibat buruknya sanitasi dan higiene, harus selalu berada dalam pemantauan petugas.

Biasanya seiring minggu-minggu berlalu setelah bencana, masyarakat semakin kurang peduli dengan risiko epidemik di wilayah yang tertimpa bencana,untuk mencegah memburuknya masalah kesehatan masyarakat korban bencana, masyarakat memerlukan bantuan dan tindakan penanggulangan, masa ini disebut masa tanggap darurat. Keberhasilan masa tanggap darurat sangat tergantung pada informasi awal adanya kedaruratan bencana sehingga surveilens penyakit menjadi suatu keharusan untuk sistim pemantauan wilayah setempat. Upaya promosi kesehatan mempunyai peran sangat bermakna untuk mengatasi ketidakberdayaan masyarakat dalam bidang kesehatan pada pasca bencana. (Kessaram, 2011).

\section{Persepsi tentang penampungan sementara}

Dari hasil penelitian lebih dari separuh (78\%) responden menyatakan setuju dengan penempatan korban di penampungan sementara dan menanggapi hal tersebut sebagai suatu alternative terbaik. Walaupun UU nomor 24 tahun 2007 telah mengatur hak dan kewajiban masyarakat, serta tanggung jawab dan wewenang pemerintah dalam penanggulangan bencana, namun alternatif itu seharusnya menjadi pilihan terakhir bagi masyarakat.

Komunitas permanen dicirikan dengan ikatan sosial mereka. Di penampungan penduduk memiliki ikatan sosial yang lemah. Sementara masyarakat di penampungan akan menggunakan fasilitas layanan yang sama dan memiliki kebutuhan yang sama, sehingga sulit membuat mekanisme sistim kewajiban bersama yang dikembangkan untuk mengatur perilaku. Misalnya dalam mekanisme sistim pembuangan limbah dan air kotor dan penggunaan jamban, karena rendahnya ikatan sosial yang dimiliki oleh sesama masyarakat penampungan, sulit memastika siapa yang akan bertanggung jawab dalam pemeliharaan kebersihan jamban. Sehingga pada akhirnya hal ini memberi kontribusi terhadap penyebaran penyakit. (PAHO, 2006)

Jika memang bencana yang menimbulkan kerusakan berat pada tempat tinggal penduduk, sehingga memaksa penduduk untuk pindah ke penampungan, maka pendirian tempat penampungan sementara harus melalui kajian yang tepat sehingga tidak mempengaruhi kesehatan penghuninya.

\section{Persepsi tentang masa pemulihan dari bencana}

Dari hasil penelitian kurang dari separuh (40\%) responden menjawab setuju atas pernyataan bahwa kondisi akan kembali normal setelah beberapa minggu. Pengaruh bencana memang berlangsung dalam waktu yang lama, apalagi bencana gempa bumi yang kekuatannya di atas 6 SR biasanya akan mengakibatkan runtuhnya bangunan. Tidak hanya bangunan yang menjadi sarana tempat-tempat umum akan tetapi juga perumahan milik penduduk serta kondisi kesehatan pada beberapa masyarakat yang menjadi pasien paraplegic seperti trauma otak atau patah tulang sehingga diamputasi.

Lamanya dampak juga dapat terjadi secara psikis karena kenangan indah bersama keluarga yang meninggal dunia akibat bencana menjadi kenangan 
pahit saat kehilangan orang yang dicintai secara tibatiba. Dampak bencana memerlukan peranan masyarakat, swasta dan pemerintah untuk menangani dan mengantisipasinya agar masyarakat menjadi lebih kuat/tahan terhadap bencana. Kementrian kesehatan telah mempunyai formula dengan program Desa Siaga Aktif dimana masyarakat desa/kelurahan/nagarinya diharapkan tahu, mau dan mampu menghadapi masalah kesehatan di wilayahnya, termasuk siaga terhadap bencana. Dengan demikian masyarakat yang telah menjadi masyarakat siaga akan lebih tahan dan mempunyai daya lenting sehingga dapat segera bangkit kembali jika terjadi bencana. Sebagai masyarakat yang hidup di Negara yang secara geografis dan geologisnya rawan terhadap bencana, masyarakat Indonesia harus berani menghadapi risiko bencana dan membangun kesiapan agar menjadi masyarakat yang kuat dan tidak menyerah dengan kondisi tersebut.

\section{KESIMPULAN}

Masyarakat Kenagarian Sumani yang menyatakan setuju terhadap pernyataan persepsi adalah $65 \%$ pasrah terhadap kejadian bencana. Namun $89 \%$ masyarakat yakin mereka dapat berkontribusi dalam penanggulangan dan melakukan usaha pengurangan risiko dampak bencana. $81 \%$ responden yakin kewaspadaan dapat mengurangi risiko bencana, namun bantuan internasional tetap mereka butuhkan, terutama bantuan medis (68\%). 77\% responden berpersepsi bencana gempa dapat diikuti dengan epidemi dan wabah penyakit sehingga perlu upaya pencegahan penyakit, $78 \%$ responden setuju tinggal di penampungan sementara. Sementara responden yang kurang dari separuh setuju dengan pernyataan persepsi adalah pernyataan bahwa mereka mampu mengambil tanggung jawab atas kelangsungan hidup mereka sendiri pasca gempa $(43 \%)$, dan pemulihan pasca gempa dapat dilakukan dalam waktu yang tidak terlalu lama $(40 \%)$.

\section{SARAN}

Masyarakat Indonesia tinggal di daerah yang rawan gempa, sehingga harus berani hidup bersama risiko gempa bumi. Keberanian hidup bersama risiko bencana ditunjukkan dengan tindakan siap siaga terhadap ancaman bencana dan meningkatkan kemampuan untuk mengurangi risiko dampak (mitigasi) bencana. Pendidikan tentang bencana harus terus menerus dilakukan agar masyarakat siap dan memiliki kemampuan untuk mencegah, mengantisipasi, menghindar dan bangkit kembali setelah kejadian bencana. Kesehatan masyarakat khususnya bidang promosi kesehatan perlu secara serius menyukseskan Program Desa siaga aktif agar masyarakat tahu, mau dan mampu menjadi desa siaga bencana.

\section{DAFTAR PUSTAKA}

Bakornas Penanggulangan Bencana. Pengenalan Karakteristik Bencana dan Upaya Mitigasinya di Indonesia. Edisi II. tahun 2007.

Fatmah, Model Mitigassi Kebakaran Berbasis Masyarakat. Jurnal Kesmas Nasional, vol 4 no. 3, Desember 2009

Majalah Interaksi, No.2/ tahun IX/2007.ISSN 0216-017X Bencana bukan keniscayaan. Pusat Promosi Kesehatan - Depkes RI.

Majalah Interaksi, No.2/ tahun IX/2007.ISSN 0216-017X Kesedihan Ganda Korban Bencana, Ancaman Gangguan Mental Serius. Pusat Promosi Kesehatan - Depkes RI.

Kessaram, Tara and Signal, Louise. Disaster management Through a Health Promotion Lens, Health Promotion Forum, Keeping Up to Date No.36. Spring/Summer 2011.

Pan America Health Organization (PAHO), Bencana Alam Perlindungan Kesehatan Masyarakat, Penerbit buku EGC, tahun 2006.

Purwana, Rachmadi. Manajemen Kedaruratan Kesehatan Lingkungan dalam Kejadian Bencana. Jakarta. Rajagrafindo Persada. 2013.

Wacana, Petrasa, Hakim, Lukman. Sistim Penyelenggaraan Penanggulangan Bencana, seri Pelatihan Tata Kelola Pengurangan Risiko Bencana, Modul 1, Penerbit; Perkumpulan IDEA, tahun 2012.

Profil Kenagarian Sumani - Kec. X Koto Singkarak, Kabupaten Solok tahun 2013.

Yayasan IDEP. Panduan Penanggulangan Bencana Berbasis Masyarakat, tahun 2007.

Yayasan Jambo Minda, Panduan Pendidikan Penanggulangan Bencana Untuk Sekolah. tahun 2010. 